\title{
PENYAJIAN DAN PENGUNGKAPAN DANA NON HALAL PADA LAPORAN KEUANGAN BAZNAS KOTA YOGYAKARTA
}

\author{
Ria Anisatus Sholihah \\ Prodi Akuntansi Syariah FEBI IAIN Pekalongan \\ Email: riaanisatus@gmail.com
}

\author{
Keywords: \\ PSAK 109, BAZNAS, zakat \\ accounting, Infak/alms, \\ non halal fund.
}

Kata Kunci:

PSAK 109; BAZNAS; Akuntansi Zakat, Infak/Sedekah; Dana Non

Halal

\section{Abstract}

Zakat Management Organization is an institution that has functions to process collection and distribution of zakat. The preparation of OPZ financial statements is guided by PSAK 109 concerning of Zakat, infaq, and alms accounting. In carrying its operational activities, BAZNAS in Yogyakarta has transactions with Conventional Financial Institutions, which is the existence income of bank and demand deposits from conventional banks. Transactions with conventional banks cause receipt or income that can be categorized as non-halal funds so they must be disclosed in the financial statements. This study aims to determine the description of non-halal funds and the disclosure and presentation of non-halal funds in the financial statements of BAZNAS in Yogyakarta started in 2016-2018. This study used qualitative research with descriptive approach. Data collection used documentation technique. Data analysis used qualitative data analysis techniques which are inductive. The results showed that the presentation and disclosure of non-halal funds of BAZNAS in Yogyakarta in 2016-2018 was in accordance with PSAK 109. Receipt of Non-halal funds that come from bank rate receipts, current accounts (conventional banks), and or other non-sharia funds have separated from zakat, donations or alms, and amil funds. The non-halal funds use needs to be separated from the expenditure of BAZNAS in Yogyakarta operational expenses and must be transfered for activities that assist public facilities construction.

\footnotetext{
Abstrak

Organisasi Pengelola Zakat merupakan institusi yang berfungsi untuk mengumpulkan serta menyalurkan zakat. Penyusunan laporan keuangan OPZ berpedoman pada PSAK 109 tentang Akuntansi Zakat, infak, dan sedekah. Dalam melakukan kegiatan operasionalnya, BAZNAS Kota Yogyakarta memiliki transaksi dengan Lembaga Keuangan Konvensional sehingga menimbulkan adanya pendapatan bunga bank dan bonus giro dari bank konvensional. Pendapatan yang muncul dari transaksi dengan bank konvensional tersebut dapat dikategorikan sebagai dana non halal sehingga harus diungkapkan dalam laporan keuangan. Penelitian ini memiliki tujuan untuk mengetahui gambaran dana non halal serta pengungkapan dan penyajian dana non halal pada laporan keuangan BAZNAS Kota Yogyakarta mulai tahun 2016-2018. Penelitian ini merupakan penelitian kualitatif dengan pendekatan deskriptif. Pengumpulan data dilakukan dengan teknik dokumentasi. Analisis data menggunakan teknik analisis data kualitatif yang bersifat induktif. Hasil penelitian menunjukkan bahwa penyajian dan pengungkapan dana non halal pada Laporan Keuangan BAZNAS Kota Yogyakarta tahun 2016-2018 telah sesuai dengan PSAK 109. Penerimaan non halal yang berasal dari penerimaan bunga bank, jasa giro (bank konvensional), dan atau dana non syariah lainnya telah terpisah dari dana zakat, infak/sedekah, dan dana amil. Penggunaan dana non halal perlu dipisahkan dari pengeluaran beban operasional BAZNAS Kota Yogyakarta dan harus disalurkan untuk kegiatan membantu pembangunan fasilitas umum.
} 


\section{PENDAHULUAN}

Organisasi Pengelola Zakat (OPZ) merupakan lembaga yang memiliki fungsi untuk peningkatan kesadaran dan pengawasan masyarakat terhadap pengelolaan zakat sesuai dengan UU No.23 tahun 2011. Pengelolaan Zakat merupakan kegiatan mulai dari perencanaan, pelaksanaan, dan pengorganisasian dalam proses pengumpulan dan penyaluran zakat. Tujuan dari pengelolaan zakat untuk mewujudkan kesejahteraan masyarakat dan tujuan tersebut akan dapat tercapai jika pengelolaan zakat dilakukan secara baik dan professional (good zakat governance). Untuk itu, OPZ memiliki tanggung jawab besar terhadap dana yang dikelolanya sehingga OPZ harus melakukan penyusunan laporan keuangan yang kredibel dan akuntabel agar masyarakat memiliki kepercayaan terhadap OPZ.

Dalam menyusun laporan keuangan, Organisasi Pengelola Zakat harus berpedoman pada PSAK 109 yang disusun oleh Dewan Standar Akuntansi Keuangan Ikatan Akuntan Indonesia dan disahkan pada tanggal 6 April 2010 serta berlaku efektif pada 1 Januari 2012. PSAK 109 merupakan PSAK tentang Akuntansi Zakat Dan Infak/Sedekah yang mengatur tentang pengakuan, pengukuran, penyajian, dan pengungkapan transaksi zakat dan infak/sedekah. Penerapan PSAK 109 ini diharapkan dapat mewujudkan adanya keseragaman dalam pelaporan keuangan OPZ sehingga masyarakat bisa memahami laporan keuangan pengelola zakat dan turut aktif dalam melakukan pengawasan terhadap pengelolaan zakat. Penerapan PSAK 109 ini juga memiliki tujuan agar pengelolaan zakat telah sesuai dengan prinsip syariah, dan seberapa jauh pengelola zakat patuh terhadap penerapan PSAK 109 (Megawati \& Trisnawati, 2014). Meskipun OPZ wajib menyusun laporan keuangan sesuai PSAK 109, namun fakta di lapangan menyebutkan bahwa tidak semua OPZ yang ada di Indonesia dapat menerapkan PSAK no. 109 dikarenakan sebagian OPZ terkendala dalam penerapannya. Salah satu faktor kendala bagi OPZ untuk menyusun laporan keuangan sesuai PSAK 109 adalah kurangnya kualitas dan kuantitas sumber daya manusia yang dimiliki OPZ (Rahman, 2015).

Adapun OPZ yang wajib menyusun laporan keuangan sesuai PSAK 109 adalah Badan Amil Zakat Nasional (BAZNAS) dan Lembaga Amil Zakat (LAZ). BAZNAS merupakan lembaga utama yang ditunjuk pemerintah untuk mengelola zakat secara nasional dan Lembaga Amil Zakat (LAZ) adalah lembaga yang berfungsi untuk mengelola zakat yang didirikan oleh masyarakat dan telah dikukuhkan oleh pemerintah melalui Kementerian Agama. BAZNAS sebagai lembaga resmi pemerintah yang bertugas untuk mengelola zakat baik pada tingkat pusat, regional/provinsi, maupun tingkat kabupaten/kota.

Salah satu BAZNAS di tingkat kabupaten/kota adalah BAZNAS Kota Yogyakarta. BAZNAS Kota Yogyakarta merupakan badan resmi yang dibentuk oleh pemerintah berdasarkan Keputusan Direktur Jendral Bimbingan Masyarakat Islam Kementerian Agama RI Nomor DJ.II/568 Tahun 2004 yang memiliki tugas dan fungsi menghimpun dan menyalurkan zakat, Infak, dan sedekah (ZIS) pada tingkat Kabupaten/Kota. Dalam melakukan kegiatan operasionalnya, BAZNAS Kota Yogyakarta memiliki transaksi dengan Lembaga Keuangan Konvensional, yaitu adanya pendapatan bunga bank dan bonus giro dari bank kovensional. Transaksi dengan bank konvensional tersebut menimbulkan adanya penerimaan atau pendapatan yang dapat dikategorikan sebagai dana non halal sehingga harus diungkapkan dalam laporan keuangan. 
Dana non halal diartikan sebagai penerimaan atau pendapatan yang dihasilkan dari kegiatan-kegiatan yang tidak halal atau tidak sesuai ketentuan syariah. Penyaluran dana non halal dapat digunakan untuk kepentingan umum. Dana non halal harus terpisah dari dana zakat, dana infak, dan dana sedekah. Pengelolaan dana non halal tidak boleh sembarangan karena prosedur akuntansinya sudah diatur dalam PSAK dan disajikan serta diungkapkan oleh OPZ dalam keadaan yang darurat dan tidak selalu muncul dalam laporan keuangan yang sifatnya akuntabel. Menurut Harkaneri \& Reflisa (2018), pengungkapan dana non halal perlu dilakukan yaitu dengan memisahkan penggunaan pendapatan non halal pada pengalokasian dana yang bersifat konsumtif dan khususnya pinjaman produktif (qardul hasan).

Ketentuan mengenai dana non halal menurut PSAK 109 adalah dana non halal disajikan dalam necara dan diungkapkan dalam catatan atas laporan keuangan. Keberadaan dana non halal berdasarkan PSAK 109 diungkapkan oleh amil atas penerimaan dan penyaluran dana, alasan, dan jumlahnya. Dana non halal harus diungkapkan secara transparan agar dapat meningkatkan kepercayaan publik. Pengungkapan dana non halal sebagai bagian dari penerapan PSAK 109 diharapkan dapat menjadi sebuah standar dalam penyusunan laporan keuangan OPZ sehingga masyarakat dapat memahami laporan keuangan pengelola zakat (Megawati \& Trisnawati, 2014).

Meskipun PSAK 109 telah mewajibkan adanya pengungkapan dana non halal, penelitian-penelitian terdahulu mengenai dana non halal pada Organisasi Pengelola Zakat menemukan hasil bahwa masih banyak Organisasi Pengelola Zakat yang belum mengungkapkan dana non halal sesuai dengan PSAK 109. Penelitian yang dilakukan oleh Roziq \& Yanti (2013) mendapatkan hasil bahwa dana non halal pada LAZ Yatim Mandiri dan LAZ DD Surabaya belum pernah disalurkan sehingga bisa dikatakan kedua LAZ tersebut belum menerapkan kebijakan penyaluran dana non halal sesuai ketentuan PSAK 109. Selain itu, Pertiwi (2015) juga mendapatkan hasil penelitian bahwa LAZISMU Kabupaten Malang menyajikan dana zakat, dana infak/sedekah, dan lain-lain tidak dalam neraca namun disajikan secara terpisah dalam Laporan Pemasukan dan Pengeluaran Bulanan. Hasil penelitian yang dilakukan Shahnaz (2015) pada BAZNAS Provinsi SULUT dan Angraeni (2016) pada BAZNAS Kota Bitung menunjukkan bahwa dana yang masuk belum terpisah berdasarkan golongan dana zakat, dana infak atau sedekah, dana amil, dan dana non halal.

Berdasarkan latar belakang tersebut, peneliti memiliki ketertarikan untuk mengetahui bagaimana penerapan PSAK 109 pada organisasi pengelola zakat, khususnya bagaimana perlakuan akuntansi terhadap dana non halal. Untuk itu, peneliti akan melakukan penelitian tentang "Penyajian dan Pengungkapan Dana Non Halal pada Laporan Keuangan BAZNAS Kota Yogyakarta". Peneliti memilih BAZNAS Kota Yogyakarta sebagai subyek penelitian karena BAZNAS Kota Yogyakarta merupakan salah satu BAZNAS di tingkat kabupaten/kota yang berkomitmen untuk mengelola dana zakat, infak, sedekah secara transparan dan akuntabel yang terbukti dari adanya publikasi Laporan Tahunan BAZNAS Kota Yogyakarta mulai tahun 2010 sampai dengan 2018 pada website resminya. Laporan Tahunan BAZNAS Kota Yogyakarta ini terdiri dari Laporan Keuangan dan Laporan Auditor Independen. Penelitian ini memiliki tujuan untuk mengetahui gambaran dana non halal pada laporan keuangan BAZNAS Kota Yogyakarta serta pengungkapan dan penyajian dana non halal pada laporan keuangan BAZNAS Kota Yogyakarta. Peneliti mengharapkan agar penelitian ini dapat memberikan kontribusi dalam pengembangan konsep Akuntansi Zakat. 
Selain itu, penelitian ini diharapkan dapat menambah wawasan pengetahuan akademisi dan praktisi tentang akuntansi zakat khususnya perlakuan akuntansi terhadap dana non halal.

\section{TELAAH PUSTAKA}

\section{Kajian Literatur}

\section{Organisasi Pengelola Zakat (OPZ)}

Definisi pengelolaan zakat menurut Undangundang No. 23 Tahun 2011 tentang pengelola zakat adalah: kegiatan perencanaan, pelaksanaan, dan pengoordinasian dalam pengumpulan, pendistribusian, dan pendayagunaan zakat. Tujuan dari dibentuknya OPZ adalah meningkatkan peran organisasi keagamaan untuk kesejahteraan dan keadilan sosial dan meningkatkan pemberian layanan penerimaan ZIS sesuai prinsip syariah.

Organisasi Pengelola Zakat terdiri dari dua jenis, yaitu Badan Amil Zakat Nasional (BAZNAS) dan Lembaga Amil Zakat (LAZ). BAZNAS merupakan lembaga utama yang ditunjuk pemerintah untuk mengelola zakat secara nasional, baik pada tingkat pusat, regional/provinsi, maupun tingkat kabupaten/kota. Lembaga Amil Zakat (LAZ) merupakan lembaga pengelola zakat yang didirikan oleh masyarakat dan telah dikukuhkan oleh pemerintah melalui Kementerian Agama. Agar pengelolaan zakat dapat meningkatkan efektivitas dan efisiensi pelayanan dalam pengelolaan zakat, maka kelembagaan pengelola zakat harus terintegrasi dengan BAZNAS sebagai koordinator seluruh pengelola zakat, baik BAZNAS Provinsi, BAZNAS Kabupaten/Kota maupun LAZ.

Berdasarkan UU Nomor 23 Tahun 2011, BAZNAS merupakan lembaga yang berwenang melakukan tugas pengelolaan zakat secara nasional. Selanjutnya dalam PP Nomor 14 Tahun 2014 tentang Pelaksanaan UU Nomor 23 Tahun 2011 tentang Pengelolaan Zakat, BAZNAS kabupaten/kota dibentuk oleh direktur jenderal yang mempunyai tugas dan fungsi di bidang zakat pada kementerian yang menyelenggarakan urusan pemerintahaan di bidang agama atas usul bupati/walikota setelah mendapat pertimbangan BAZNAS. BAZNAS kabupaten/kota dibiayai dengan Anggaran Pendapatan dan Belanja Daerah dan Hak Amil, serta juga dapat dibiayai dengan Anggaran Pendapatan dan Belanja Negara.

BAZNAS kabupaten/kota wajib menyampaikan laporan pelaksanaan pengelolaan zakat, infak, sedekah, dan dana sosial keagamaan lainnya kepada BAZNAS provinsi dan bupati/walikota setiap 6 (enam) bulan dan akhir tahun. Laporan tersebut memuat akuntabilitas dan kinerja pelaksanaan Pengelolaan zakat, infak, sedekah, dan dana sosial keagamaan lainnya. Laporan tersebut harus diaudit syariat dan keuangan. Audit syariat dilakukan oleh kementerian yang menyelenggarakan urusan pemerintahan di bidang agama. Audit keuangan dilakukan oleh akuntan publik. BAZNAS dikenakan sanksi administratif jika tidak melakukan pencatatan dalam pembukuan tersendiri terhadap pengelolaan infak, sedekah, dan dana sosial keagamaan lainnya.

Badan Amil Zakat Nasional (BAZNAS) Kota Yogyakarta merupakan badan resmi yang dibentuk oleh pemerintah berdasarkan Keputusan Direktur Jendral Bimbingan Masyarakat Islam Kementerian Agama RI Nomor DJ.II/568 Tahun 2004 yang memiliki tugas dan fungsi menghimpun dan menyalurkan zakat, Infak, dan sedekah (ZIS) pada tingkat Kabupaten/Kota. Seiring dengan adanya regulasi tentang pengelolaan zakat, UU Nomor 38 Tahun 1999, Wali Kotamadya Yogyakarta mengeluarkan SK Nomor 274/KEP/2005 tanggal 1 Juli 2005 tentang pembentukan Badan Amil Zakat (BAZ) Kota Yogyakarta masa bakti 20052008. Akhir tahun 2009, tepatnya tanggal 1 September 2009, Walikota Yogyakarta mengeluarkan SK Nomor 432/KEP/2009 
tentang pembentukan Badan Amil Zakat Daerah Kota Yogyakarta (BAZDA).

Dengan adanya perubahan UU 38 tahun 1999 menjadi UU 23 tahun 2011 tentang Pengelolaan Zakat, BAZDA Kota Yogyakarta berubah nama menjadi BAZNAS Kota Yogyakarta dan diresmikan oleh Walikota Yogyakarta pada tanggal 3 Agustus 2012 dan diterbitkan Keputusan Walikota Yogyakarta Nomor 323 Tahun 2015 tentang pengangkatan Pimpinan dan Pelaksana Badan Amil Zakat Nasional Kota Yogyakarta periode 2015-2020. Dalam menjalankan kegiatannya, BAZNAS Kota Yogyakarta berkedudukan di Masjid Diponegoro Gedung Balaikota Yogyakarta.

Maksud dan tujuan didirikannya BAZNAS Kota Yogyakarta adalah untuk mewujudkan badan pengelola zakat yang mengedepankan prinsip amanah, transparansi, professional dan akuntabel. BAZNAS Kota Yogyakarta telah mempublikasikan Laporan Tahunan mulai tahun 2010 sampai dengan 2018 pada website resminya. Laporan Tahunan ini terdiri dari Laporan Keuangan dan Laporan Auditor Independen.

\section{PSAK 109 Tentang Akuntansi Zakat Dan Infak/Sedekah}

PSAK 109 tentang Akuntansi Zakat Dan Infak/Sedekah merupakan Standar akuntansi keuangan syariah yang bertujuan untuk mengatur Pengakuan, Pengukuran, Penyajian, serta Pengungkapan atas penerimaan dan penyaluran zakat, infak, dan sedekah. Sebelum diterbitkan PSAK 109, pengelola zakat sudah menyusun laporan keuangan namun tidak ada standar yang sama di antara pengelola-pengelola zakat sehingga menyulitkan berbagai pihak dalam membaca dan memahami laporan keuangan pengelola zakat tersebut.

Berdasarkan PSAK 109, amil adalah organisasi atau lembaga pengelola zakat yang pendiriannya bertujuan melakukan penerimaan serta penyaluran zakat, infak, dan sedekah. PSAK 109 harus dipatuhi penerapannya oleh amil yang mendapatkan izin dari regulator. PSAK 109 tidak berlaku bagi entitas syariah yang melakukan penerimaan dan penyaluran zakat, infak, dan sedekah tetapi tidak sebagai kegiatan operasional utamanya. Entitas tersebut mengacu pada PSAK 101 tentang Penyajian Laporan Keuangan Syariah (IAI, 2016).

Komponen Laporan keuangan amil zis berdasarkan PSAK 109 adalah laporan posisi keuangan (neraca), laporan perubahan dana, laporan perubahan aset kelolaan, laporan arus kas, dan catatan atas laporan keuangan. catatan atas laporan keuangan penting untuk disusun agar menjadi laporan keuangan yang dapat menggambarkan kondisi keuangan secara riil pada pengelola zakat. Dalam catatan ini disebutkan tentang kebijakan dan prosedur akuntansi yang diterapkan oleh organisasi tersebut sehingga dihasilkan angka-angka pada laporan keuangan (Megawati \& Trisnawati, 2014).

Penerimaan non halal adalah penerimaan dari kegiatan-kegiatan yang tidak sesuai prinsip syariah seperti pendapata jasa giro atau bunga yang berasal dari bank konvensional. Penerimaan non halal biasanya terjadi pada kondisi darurat atau pada kondisi yang tidak dapat dihindari. Selanjutnya, entitas syariah dapat mengungkapkan pada catatan atas laporan keuangan tentang alasan munculnya dana non halal serta penyaluran atas penerimaan non halal. Amil menyajikan dana zakat, dana infak, dana sedekah, dana amil, dan dana nonhalal secara terpisah dalam neraca atau laporan posisi keuangan. Dan keberadaan dana non halal diungkapkan oleh amil atas penerimaan dana, penyaluran dana, alasan, dan jumlahnya (IAI, 2016).

\section{Penelitian Terdahulu}

Penelitian-penelitian terdahulu mengenai dana non halal pada Organisasi Pengelola Zakat mendapatkan hasil yang beragam. Penelitian Roziq \& Yanti (2013) pada LAZ Rumah Yatim Mandiri, LAZ Rumah Zakat 
dan LAZ DD Surabaya menunjukkan bahwa perlakuan akuntansi dana non halal belum sesuai PSAK 109. Pada LAZ Rumah Zakat, dana non halal diakui untuk menambah akun dana non halal dan pada LAZ Yatim Mandiri diakui untuk menambah dana amil, sedangkan pada LAZ DD Surabaya diakui untuk menambah dana masyarakat. Sampai saat ini, dana non halal pada LAZ Yatim Mandiri dan LAZ DD Surabaya belum pernah disalurkan sehingga bisa dikatakan kedua LAZ tersebut belum menerapkan kebijakan penyaluran dana non halal sesuai ketentuan PSAK 109. Sedangkan pada LAZ Rumah Zakat, dana non halal telah disalurkan sesuai ketentuan PSAK 109 yaitu hanya disalurkan untuk biaya administrasi bank dan sarana umum.

Pada penelitian yang dihasilkan oleh Hisamuddin\&Sholikha (2014), dana non halal pada BAZNAS Kabupaten Lumajang dimanfaatkan untuk kepentingan operasional seperti perbaikan fasilitas umum yang berhubungan dengan fasilitas-fasilitas di sekolah yayasan islam. Sedangkan dana non halal di PKPU Kabupaten Lumajang dimanfaatkan untuk kepentingan sosial seperti untuk pembangunan kamar mandi mushola, perbaikan jalan, dan kegiatan lainnya. Dana non halal tersebut tidak disalurkan setiap bulan tetapi disalurkan sesuai kesepakatan atas program yang akan dilaksanakan karena tidak setiap bulan ada program baru. Adapun PKPU Kabupaten Lumajang telah menyajikan laporan dana non halal secara terpisah dari laporan dana zakat, infaq, dan sodaqoh. Sehingga dapat disimpulkan bahwa BAZNAS dan PKPU Kabupaten Lumajang telah mengungkapkan dana non halal sesuai PSAK 109.

Penelitian Megawati dan Fery (2014) menunjukkan hasil yang sama dengan penelitian Roziq \& Yanti (2013) dan Hisamuddin\&Sholikha (2014) bahwa dana non halal pada BAZNAS Kota Pekanbaru sudah dilaporkan terpisah dan berdasarkan ketentuan ulama hanya digunakan untuk pembangunan fasilitas umum serta tidak bisa digunakan untuk konsumsi perseorangan. Namun, penelitian Pertiwi (2015) justru menemukan bahwa LAZISMU Kabupaten Malang menyajikan dana zakat, dana infak, dana sedekah, tabur, dan lain-lain tidak dalam neraca namun disajikan secara terpisah dalam Laporan Pemasukan dan Pengeluaran Bulanan. Seperti penelitian Pertiwi (2015), penelitian Shahnaz (2015) juga menunjukkan bahwa dana yang masuk pada BAZNAS Provinsi SULUT belum terpisah berdasarkan golongan dana zakat, dana infak, dana sedekah, dana amil, dan dana non halal.

Hasil penelitian Angraeni (2016) pada Badan Amil Zakat Kota Bitung mendapatkan fakta bahwa BAZNAS Kota Bitung belum menerapkan penyusunan laporan keuangan sesuai dengan format laporan akuntansi keuangan zakat, infak/sedekah yang terdapat dalam PSAK 109, karena untuk penyusunannya BAZNAS Kota Bitung hanya mengacu sesuai arahan dan kebutuhan dari badan amil tersebut yang bentuknya masih berupa laporan penerimaan dan penyaluran zakat. Semua dana kas yang masuk pada BAZNAS Kota Bitung belum dipisahkan berdasarkan golongan dana zakat, dana infaq/sedekah, dana amil, serta dana non halal.

Namun, penelitian Ritonga (2017) yang menemukan bahwa BAZNAS Sumatera Utara telah mengakui dana non halal sebagai dana non ZIS dan non Amil yang terpisah dari dana zakat. Penerimaan dana non halal diakui sebagai dana non halal, yang terpisah dari dana zakat, dana infak/ sedekah dan dana amil serta disalurkan sesuai dengan syariah. Budiarti, Endang, dan Samrotun (2017) juga menghasilkan penelitian bahwa penerimaan dana nonhalal pada BAZNAS Kota Yogyakarta sudah diakui sebagai dana non halal, yang terpisah dari dana zakat, dana infaq/shadaqah dan dana amil. Penelitian Saputri (2019) mendapatkan hasil yang sama dengan Ritonga (2017) dan Samrotun (2017) yang mendapatkan hasil bahwa bahwa 
penerimaan dana non halal LAZIS ALHAROMAIN diakui sebagai dana non halal yang dalam pencatatannya disajikan terpisah dengan dana zakat, infak/sedekah. Namun pengungkapan dana non halal pada LAZIS AL-HAROMAIN belum sesuai PSAK 109 karena dalam penyajian laporan perubahan dana hanya terdapat nama akun tanpa nominal atau tidak ada transaksi selama tahun 2018.

Hasil penelitian yang beragam menunjukkan bahwa sekalipun PSAK 109 telah menentukan perlakuan akuntansi untuk dana non halal pada BAZNAS dan LAZ, namun sebagian dari organisasi pengelola zakat tersebut belum mematuhi PSAK 109. Sehingga dapat dikatakan bahwa organisasi pengelola zakat tersebut belum membuat laporan keuangan secara transparan dan akuntabel yang dapat berdampak terhadap menurunnya tingkat kepercayaan pihak-pihak yang akan menyalurkan zakat.

Hasil penelitian terdahulu yang beragam dapat menjadi peluang adanya penelitian baru untuk mengetahui apakah dana non halal telah disajikan dan diungkapkan sesuai PSAK 109 terutama pada organisasi pengelola zakat lainnya yang ada di tingkat daerah baik itu provinsi maupun kabupaten/kota. Untuk itu, penelitian ini memilih subyek penelitian yang berbeda dengan penelitian-penelitian terdahulu, yaitu BAZNAS Kota Yogyakarta. Selain perbedaan subyek penelitian, perbedaan lainnya adalah penelitian ini berusaha untuk membandingkan penyajian dan pengungkapan dana non halal dari tahun 2016 sampai dengan tahun 2018 untuk menilai konsistensi atas kepatuhan pada PSAK 109. Perbedaan selanjutnya adalah penelitian ini menggunakan data sekunder yaitu Laporan Tahunan yang telah diaudit dan dipublikasikan BAZNAS Kota Yogyakarta di website resminya sehingga mendukung asas transparansi dan akuntabel dalam pengelolaan dana zakat, infak/sedekah, dan dana lainny.

\section{METODE PENELITIAN}

Penelitian ini adalah jenis penelitian kualitatif dengan pendekatan deskriptif. Desain penelitian pada penelitian kualitatif ini menggunakan desain studi kasus yang mengeksporasi isu secara spesifik dan kontekstual secara mendalam. Penelitian ini menggunakan data sekunder, yaitu data atau informasi yang diperoleh secara tidak langsung dari subyek penelitian yang bersifat publik, seperti data kearsipan, dokumen, laporan yang berkaitan dengan penelitian ini. Data sekunder dalam penelitian ini berupa informasi laporan keuangan BAZNAS Kota Yogyakarta selama Tahun 2016-2018 yang telah diaudit dan dipublikasikan di situs resmi BAZNAS Kota Yogyakarta. Data dikumpulkan dengan teknik dokumentasi yaitu dengan cara memperoleh data melalui dokumen yang dipublikasikan yang berkaitan dengan subyek dan fokus penelitian ini. Dokumen yang digunakan dalam penelitian ini adalah informasi laporan keuangan BAZNAS Kota Yogyakarta selama Tahun 2016-2018 yang telah diaudit dan dipublikasikan di situs resmi BAZNAS Kota Yogyakarta.

(https://baznas.jogjakota.go.id/Home/laporan (tahunan)

Penelitian ini menggunakan analisis data kualitatif yang bersifat induktif yaitu analisis atas data yang diperoleh, dan dikembangkan suatu pola hubungan (Sugiyono, 2014). Tiga komponen utama analisis kualitatif dengan interactive model menurut Sugiyono (2014) adalah Reduksi data (data reduction), Penyajian data (data display), dan Penarikan kesimpulan atau verifikasi (conclusion drawing/verification).

Reduksi data dilakukan setelah proses pengumpulan data dengan cara membuat ringkasan yang dimulai dari penggolongan data penting dan membuang data yang tidak diperlukan. Ringkasan ini akan diorganisasikan dan disajikan hingga dapat ditarik kesimpulan finalnya. Setelah data 
direduksi, langkah selanjutnya adalah penyajian data, yaitu data-data yang disusun agar mudah dibaca sehingga dapat ditarik kesimpulan. Penyajian data ini bisa menggunakan tabel, grafik, matrik, dan lain sebagainya. Langkah terakhir setelah data disajikan adalah penarikan kesimpulan yang harus diverifikasi dengan melakukan analisis dan tinjauan terhadap catatan-catatan penting yang sudah dikumpulkan bersama data lainnya. Kesimpulan akhir perlu dilakukan verifikasi agar hasil penelitian ini dapat dipertanggungjawabkan.

Tabel 1

Penyajian dan Pengungkapan Dana Non Halal Pada BAZNAS Kota Yogyakarta

\begin{tabular}{|c|c|c|c|c|}
\hline NO & KETERANGAN & 2016 & 2017 & 2018 \\
\hline \multirow[t]{3}{*}{1} & LAPORAN POSISI KEUANGAN & & & \\
\hline & SALDO DANA (kredit) & & & \\
\hline & Dana Nonhalal & 8.945 .342 & 7.825 .174 & 11.309 .530 \\
\hline \multirow[t]{7}{*}{2} & LAPORAN PERUBAHAN DANA & & & \\
\hline & Saldo Awal & 5.119 .210 & 8.945 .342 & 7.825 .174 \\
\hline & Penerimaan & & & \\
\hline & - Penerimaan Bunga Bank & & & \\
\hline & $\begin{array}{l}\text { - Penerimaan Jasa Giro Non Syariah } \\
\text { Penggunaan }\end{array}$ & 4.367 .632 & 3.379 .832 & 3.484 .356 \\
\hline & - Sarana Prasarana Kantor & $(541.500)$ & $(4.500 .000)$ & - \\
\hline & Saldo Akhir & 8.945 .342 & 7.825 .174 & 11.309.530 \\
\hline \multirow[t]{5}{*}{3} & LAPORAN ARUS KAS & & & \\
\hline & Arus Kas Dari (Untuk) Aktivitas Operasi & & & \\
\hline & Penerimaan Dana Non halal & 4.367 .632 & 3.379 .832 & 3.484 .356 \\
\hline & Penggunaan Dana Non Halal & & $(4.500 .000)$ & - \\
\hline & Beban Operasional dan Pengeluaran Lain & $(21.841 .500)$ & & \\
\hline
\end{tabular}

4 CATATAN ATAS LAPORAN KEUANGAN

Penjelasan Pos-Pos Laporan Keuangan

Saldo akhir dana non halal

8.945.342

Penerimaan Dana Amil (Operasional)

4.367 .632

Dana Non Halal

Penggunaan Dana Amil (Operasional)

Beban Operasional dan pengeluaran lainnya

Renovasi Kantor BAZNAS

Informasi Yang Mendukung Laporan

Keuangan

Saldo dana

Dana Non Halal

7.825 .174

Penerimaan Dana Non Halal

Penerimaan Bonus Giro Non Syariah

Penggunaan Dana Non Halal

Belanja Sarana Prasarana

SALDO DANA NON HALAL

Saldo Awal

7.825 .174

Penerimaan Non Halal

Pengeluaran Non Halal

Saldo Akhir

\section{HASIL DAN PEMBAHASAN \\ Pengungkapan dan Penyajian Dana Non Halal BAZNAS Kota Yogyakarta}

BAZNAS Kota Yogyakarta telah menyusun Laporan Keuangan yang terdiri dari: Laporan Posisi Keuangan, Laporan Perubahan Dana, Laporan Perubahan Aset Kelolaan, Laporan Arus Kas, Catatan Atas Laporan Keuangan. Berikut adalah penyajian dan pengungkapan terhadap Dana Non Halal pada BAZNAS Kota Yogyakarta : 
Kesesuaian Neraca BAZNAS Kota Yogyakarta Dengan PSAK 109

Penerimaan non halal adalah semua penerimaan dari transaksi yang tidak sesuai prinsip syariah seperti pendapatan jasa giro atau bunga yang berasal dari bank konvensional. Penerimaan non halal biasanya pada kondisi darurat atau kondisi yang tidak dapat dihindari. Entitas syariah dapat mengungkapkan dalam catatan atas laporan keuangan tentang alasan terjadinya dana non halal dan penggunaan dana non halal. Selanjutnya, Amil menyajikan dana zakat, dana infak, dana sedekah, dana amil, dan dana non halal secara terpisah dalam neraca atau laporan posisi keuangan. Keberadaan dana non halal

\section{Grafik 1}

Pengungkapan Saldo Dana Non Halal Baznas Kota Yogyakarta Di Neraca

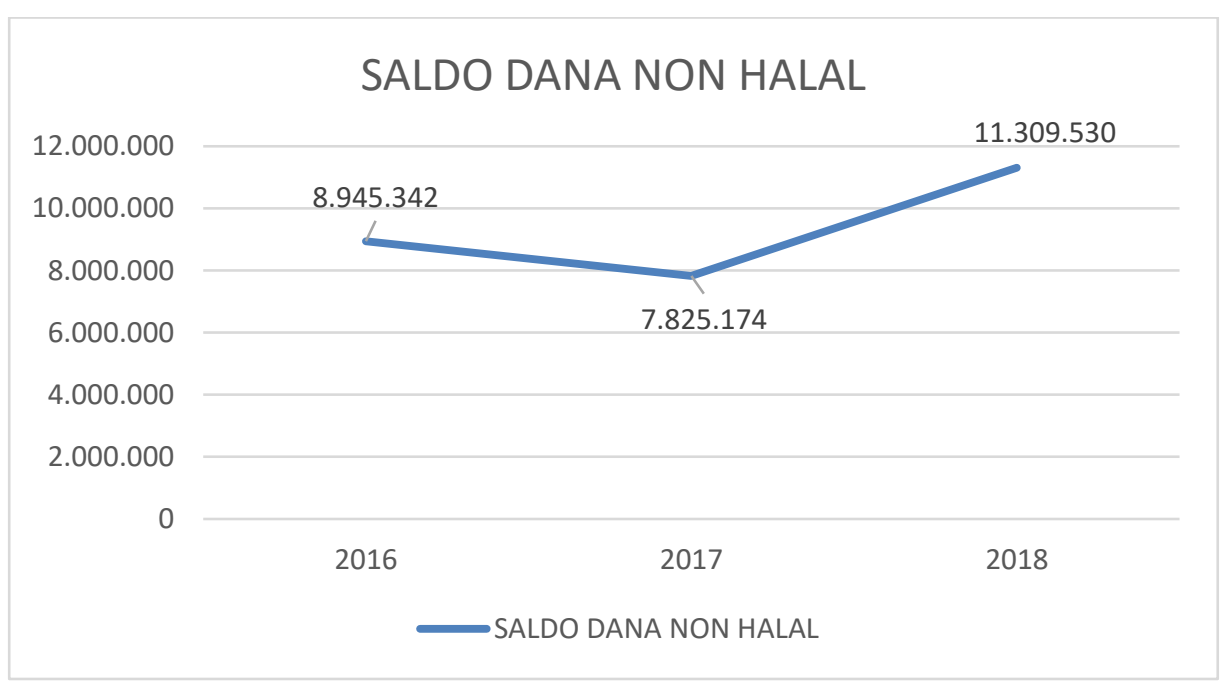

Kesesuaian Laporan Perubahan Dana BAZNAS Kota Yogyakarta Dengan PSAK 109

Laporan Perubahan Dana BAZNAS Kota Yogyakarta mengungkapkan bahwa Penerimaan dana non halal pada BAZNAS Kota Yogyakarta diperoleh dari penerimaan jasa giro non syariah karena BAZNAS Kota Yogyakarta memiliki rekening di Bank Konvensional, yaitu : Bank BRI, Bank BPD, dan Bank Jogja. Dana non halal pada tahun 2016 digunakan untuk sarana dan prasarana kantor yaitu renovasi kantor BAZNAS. Dan pada tahun 2017 untuk Belanja Sarana Prasarana. Namun, untuk tahun 2018 tidak tersaji adanya penggunaan dana non halal. Penerimaan dan penggunaan dana non halal yang disajikan pada Laporan Perubahan Dana disajikan dalam grafik berikut ini:

\section{Grafik 2 \\ Pengungkapan Penerimaan dan Penggunaan Dana Non Halal Baznas Kota Yogyakarta Pada Laporan Perubahan Dana}




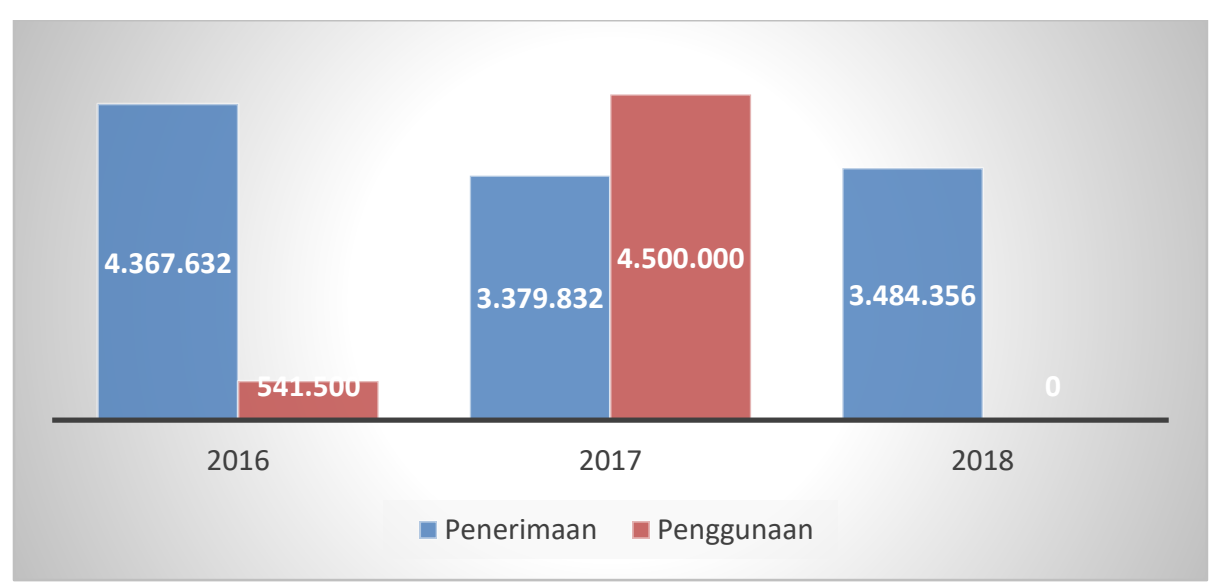

Kesesuaian Laporan Arus Kas BAZNAS Kota Yogyakarta Dengan PSAK 109

Laporan Arus Kas BAZNAS Kota Yogyakarta mengungkapkan bahwa Arus Kas dari (untuk) Aktivitas Operasi yang berasal dari penerimaan dana non halal adalah Tahun 2016 sebesar 4.367.632, Tahun 2017 sebesar 3.379.832, Tahun 2018 sebesar 3.484.356. Penggunaan dana non halal yang disajikan pada Laporan Arus Kas BAZNAS Kota Yogyakarta hanya pada Tahun 2017 sebesar 4.500.000 karena pada tahun 2018 tidak ada penggunaan dana non halal. Sedangkan pada tahun 2016, penggunaan dana non halal sebesar 541.500 dicatat dalam satu akun yaitu Beban Operasional dan Pengeluaran Lain sebesar 21.841.500. Padahal dalam Catatan Atas Laporan Keuangan telah diungkapkan bahwa pembayaran Beban Operasional dan Pengeluaran Lain tahun 2016 sebesar 21.300.000 menggunakan Dana Amil (Operasional) yang berasal dari dana operasional APBD sehingga seharusnya penggunaan dana non halal disajikan terpisah dalam akun tersendiri.

\section{Kesesuaian Catatan Laporan Keuangan BAZNAS Kota Yogyakarta Dengan PSAK 109}

Entitas syariah dapat mengungkapkan dalam catatan atas laporan keuangan tentang alasan terjadinya dan penggunaan atas penerimaan non halal. Selanjutnya, Amil menyajikan dana zakat, dana infak/ sedekah, dana amil, dan dana nonhalal secara terpisah dalam neraca (laporan posisi keuangan). Keberadaan dana non halal diungkapkan oleh amil atas penerimaan dan penyaluran dana, alasan, dan jumlahnya (IAI, 2016). BAZNAS Kota Yogyakarta telah mengungkapkan dana non halal dalam Catatan Atas Laporan Keuangan sesuai PSAK 109.

Dalam Catatan Atas Laporan Keuangan BAZNAS Kota Yogyakarta Tahun 2016 dana non halal diungkapkan pada bagian Penjelasan Pos-Pos Laporan Keuangan meliputi: saldo awal, Penerimaan Dana Amil (Operasional) yang berasal dari dana non halal, penggunaan Dana Amil (Operasional) berupa Beban Operasional dan pengeluaran lainnya untuk renovasi kantor BAZNAS, dan saldo akhir dana non halal. Dana non halal BAZNAS Kota Yogyakarta pada tahun 2017 diungkapkan dalam Catatan Atas Laporan Keuangan pada bagian Ikhtisar Kebijakan Akuntansi dan bagian Informasi Yang Mendukung Laporan Keuangan meliputi Penerimaan Bonus Giro Non Syariah, penggunaan dana non halal berupa Belanja Sarana Prasarana, dan Saldo Dana.

Seperti pada tahun 2017, Dana non halal BAZNAS Kota Yogyakarta pada tahun 2018 diungkapkan dalam Catatan Atas Laporan Keuangan pada bagian Ikhtisar Kebijakan Akuntansi bahwa Dana non syariah merupakan dana yang dibentuk untuk menampung penerimaan bunga bank, jasa giro (bank konvensional), dan atau dana non syariah lainnya yang harus dipisahkan dari dana zakat, dana infak/sedekah dan dana amil karena peruntukannya yang sangat khusus. Jasa giro bank konvensional dikelompokkan ke dalam Dana Non Syariah dan disalurkan untuk kegiatan membantu pembangunan fasilitas 
umum. Dalam Catatan Atas Laporan Keuangan BAZNAS Kota Yogyakarta tahun 2018 juga diungkapkan saldo awal, penerimaan non halal, pengeluaran non halal, dan saldo akhir.

Dari hasil penelitian tersebut, dapat dilihat bahwa penyajian dan pengungkapan dana non halal pada BAZNAS Kota Yogyakarta telah sesuai dengan PSAK 109. Penyusunan Laporan Keuangan BAZNAS Kota Yogyakarta juga telah sesuai dengan PSAK 109. Penyajian dan pengungkapan dana non halal yang awalnya pada tahun 2016 masih belum sesuai karena penggunaan dana non halal sebesar 541.500 dicatat dalam satu akun yaitu Beban Operasional dan Pengeluaran Lain sebesar 21.841.500. Padahal dalam Catatan Atas Laporan Keuangan telah diungkapkan bahwa pembayaran Beban Operasional dan Pengeluaran Lain tahun 2016 sebesar 21.300.000 menggunakan Dana Amil (Operasional) yang berasal dari dana operasional APBD sehingga seharusnya penggunaan dana non halal disajikan terpisah dalam akun tersendiri.

Penyajian dan pengungkapan dana non halal tahun 2017 dan 2018 berbeda dengan tahun 2016 karena telah dibuat akun khusus penggunaan dana non halal yang tidak lagi bercampur dengan Beban Operasional dan Pengeluaran Lain. Selain itu, dalam catatan laporan keuangan BAZNAS Kota Yogyakarta tahun 2017 dan 2018 telah mengungkapkan tentang Ikhtisar Kebijakan Akuntansi yang mencantumkan pengertian dan ruang lingkup dana non halal tersebut.

\section{SIMPULAN}

Secara umum, penyajian dan pengungkapan dana non halal pada BAZNAS Kota Yogyakarta telah sesuai dengan PSAK 109. BAZNAS Kota Yogyakarta perlu menjaga prinsip bahwa penerimaan nonhalal pada umumnya terjadi dalam kondisi darurat atau kondisi yang tidak diinginkan oleh entitas syariah karena secara prinsip dilarang sehingga penyaluran atau penggunaan dana non halal harus sesuai dengan aturan yang ada. Penerimaan non halal yang berasal dari penerimaan bunga bank, jasa giro (bank konvensional), dan atau dana non syariah lainnya yang harus benar-benar dipisahkan dari dana zakat, dana infak/sedekah dan dana amil. Penggunaan dana non halal perlu dipisahkan dari pengeluaran beban operasional BAZNAS Kota Yogyakarta dan harus disalurkan untuk kegiatan membantu pembangunan fasilitas umum. Dalam penyajian dan pengungkapan dana non halal pada BAZNAS Kota Yogyakarta diharapkan tetap transparan dan akuntabel, sehingga akan menjaga dan meningkatkan kepercayaan masyarakat terhadap BAZNAS Kota Yogyakarta sebagai lembaga pengelola zakat.

\section{REFERENSI}

Angraeni, Elvinda Febry, Pangemanan, Sifrid S, Rondonuwu, Sintje S. (2016). Penerapan Akuntansi Zakat Dan Infak/Sedekah Berdasarkan PSAK 109 Pada Badan Amil Zakat Kota Bitung. Jurnal EMBA Vol.4 No.4 September 2016, Hal. $1191-1199$

Budiarti, Amita Vani \& Masitoh, Endang \& Yuli Chomsatu Samrotun. (2017). Evaluasi Penerapan PSAK 109 Tentang Pelaporan Keuangan Akuntansi Zakat, Infaq/Shadaqah Pada BAZNAS Kota Yogyakarta. Jurnal Akuntansi dan Sistem Teknologi Informasi Vol. 1342 No. 1 Maret 2017: 41 - 47

Harkaneri \& Reflisa, Hana. (2018). Pendapatan Non Halal Sebagai Sumber Dan Penggunaan Qardhul Hasan Dalam Perspektif Islam. SYARIKAT : Jurnal Rumpun Ekonomi Syariah Volume 1 Nomor 2, Desember 2018

Hisamuddin, N., \& Sholikha, I. H. (2014). Persepsi, Penyajian dan Pengungkapan Dana Non Halal pada BAZNAS dan PKPU Kabupaten Lumajang. ZISWAF Jurnal Zakat Dan Wakaf, 1(1), 1-36.

Ikatan Akuntan Indonesia. (2016). Standar Akuntansi Keuangan Syariah Efektif Per 1 Januari 2017. Jakarta : Ikatan Akuntan Indonesia

Lenap, Indria Puspitasari. (2019). Pengungkapan Pendapatan Non-Halal: Psak 109 Vs Praktik. Jurnal Aplikasi Akuntansi Vol 3 no 2 (2019), April 2019

Megawati, Devi\& Trisnawati, Fenny. (2014). Penerapan PSAK 109 Tentang Akuntansi Zakat Dan Infak/Sedekah Pada Baz Kota Pekanbaru. Kutubkhanah: Jurnal Penelitian sosial keagamaan, Vol.17, 
No.1 Januari-Juni 2014

Pertiwi, Rita Anggun, Masiyah Kholmi, Eris

Tri Kurniawati. (2015). Analisis Penerapan Akuntansi Dana Zakat Dan Infak/Sedekah Pada Lembaga Amil Zakat Infak, Dan Shodaqoh Muhammadiyah (LAZISMU) Kabupaten Malang. Jurnal Reviu Akuntansi dan Keuangan Vol.5 No. 2, Oktober 2015 Pp 751-758

Rahman, Taufikur. (2015). Akuntansi Zakat, Infak dan Sedekah (PSAK 109) : Upaya Peningkatan Transparansi dan Akuntabilitas Organisasi Pengelola Zakat (OPZ). Jurnal Muqtasid Volume 6, Nomor 1, Juni 2015

Ritonga, Pandapotan. (2017). Analisis akuntansi zakat berdasarkan PSAK No. 109 pada Badan Amil Zakat Nasional (BAZNAS) Sumatera Utara. Jurnal Kitabah: Volume 1. No. 1 Januari-Juni 2017

Roziq, A., \& Yanti, W. (2013). Pengakuan, Pengukuran, Penyajian Dan Pengungkapan Dana Non Halal Pada Laporan Keuangan Lembaga Amil Zakat. Jurnal Akuntansi Universitas Jember, 11 No.2, 20-47.

Saputri, Tiara Dewi \& Diana, Nur \& Mawardi, M. Cholid. (2019). Analisis Penerapan PSAK 109 Pada Lembaga Amil Zakat Di Kota Batu (Studi Kasus pada LAZIS ALHAROMAIN dan LESMA AN-NUUR Kota Batu). E-JRA Vol. 08 No. 01 Februari 2019 Hal.54-67

Shahnaz, S. (2015). Penerapan PSAK No.109 Tentang Pelaporan Keuangan Akuntansi Zakat, Infaq/Sedekah Pada Badan Amil Zakat Provinsi Sulawesi Utara. Jurnal EMBA, 3(4), 315-324.

Sugiyono. (2014). Metode Penelitian Bisnis (Pendekatan Kuantitatif, Kualitatif, dan $R \& D)$. Bandung : Alfabeta 